\title{
PENGARUH MODEL PEMBELAJARAN DIRECT INSTRUCTION BERBANTUAN BAHAN AJAR BERBASIS KONTEKSTUAL TERHADAP HASIL BELAJAR IPA TERAPAN SISWA KELAS X SMKN 4 MATARAM TAHUN AJARAN 2015/2016
}

\author{
Puryadi*, Satutik Rahayu, Sutrio \\ Program Studi Pendidikan Fisika, Universitas Mataram \\ *Email: puryadifisika2012@ gmail.com
}

\begin{abstract}
This study aims to determine the effect learning model of direct instruction assisted contextual based teaching materials to the students learning outcomes of applied science SMKN 4 Mataram of academic years 2015/2016 on temperature and heat matter. This type of research is an experimental study with post test design control group design. The population in this study were all students of class X SMKN 4 Mataram of academic years 2015/2016. Sampling is done by purposive sampling technique, selected of X2 culinary class as experiment class and student of class X3 culinary as control class. The teaching materials used are context based physics teaching materials to culinary students. Instruments used in the form of multiple-choice test questions that refer to students' cognitive abilities include C1 to C6 categories. The results showed that the mean values of the students' learning outcomes of the experimental class and control classes were 61.38 and 49.07, respectively, both classes were normal and homogeneously distributed. The results data were analyzed by two-party test with a significance level of $5 \%$ obtained $t_{\text {rsesult }} 2.89$ and $t_{\text {table }} 2.00$. If $t_{\text {result }}>t_{\text {table. }}$ So $H_{o}$ is rejected and $H_{a}$ is accepted. So it can be concluded that there is the influence learning model of direct instruction that is assisted by contextual based teaching materials on the learning outcomes of students of class $X$ SMKN 4 Mataram of academic years 2015/2016.
\end{abstract}

Keywords: direct instruction, contextual based teaching materials, learning outcomes

\section{PENDAHULUAN}

Berdasarkan struktur Kurikulum 2013, mata pelajaran Ilmu Pengetahuan Alam (IPA) di SMK Pariwista termasuk ke dalam mata pelajaran dasar bidang kejuruan yang dikenal dengan istilah IPA Terapan. IPA Terapan merupakan ilmu yang termasuk rumpun IPA yaitu Biologi, Kimia, dan Fisika. Oleh karena itu IPA Terapan mempunyai karakteristik yang sama dengan IPA.

Menurut Murniati, et al., (2011). Ilmu Pengetahuan Alam (IPA) merupakan deretan konsep dan skema konseptual yang berhubungan satu sama yang lain dan yang tumbuh sebagai hasil dari eksperinmentasi dan observasi serta berguna untuk diamati dan dieksperimentasi lebih lanjut. Sedangkan menurut Mahedy (2010) pendidikan IPA menekankan pada pemberian pengalaman langsung dan kegiatan praktis untuk mengambangkan kompetensi agar siswa mampu menjelajahi dan memahami alam sekitar secara ilmiah. Dalam penelitian ini bidang materi dari mata pelajaran IPA terapan yang akan diteliti adalah fisika.

Fisika merupakan bagian dari Sains yang memfokuskan kajiannya pada materi, energi dan hubungan antara keduanya (Gunawan, et al., 2015). Menurut Gunada, et al., (2015) Fisika adalah bidang Ilmu Pengetahuan Alam (IPA) yang menyediakan pengalaman untuk memahami konsep dan dan kemampuan memacahkan masalah. Nisrina et al. (2016) juga mengungkapkan bahwa Fisika memiliki subjek yang kaya akan pengetahuan dan hukum-hukum fisika yang diformulasikan dalam bentuk matematis. Pemahaman konsep pada materi fisika suhu dan kalor disajikan dalam bentuk bahan ajar yang disusun secara kontekstual terhadap kehidupan sehari-hari siswa SMK Pariwisata. 
Keberhasilan dalam pembelajaran materi fisika di SMK Pariwisata ditentukan dengan kualitas atau mutu Pendidikan di sekolah tersebut. Salah satu upaya untuk meningkatkan mutu pendidikan dan keberhasilan siswa dalam mempelajari materi Fisika adalah dengan cara memperbaiki proses pembelajaran. Proses pembelajaran yang dimaksud adalah dengan memperbaiki cara mengajar dengan menggunakan model pembelajaran dan bahan ajar yang sesuai dengan kondisi siswa. Model pembelajaran merupakan cara yang digunakan untuk mengimplementasikan rencana yang sudah disusun dalam bentuk kegiatan nyata dan praktis untuk mencapai tujuan pembelajaran, sedangkan bahan ajar merupakan segala bahan baik tertulis maupun tidak tertulis yang digunakan untuk membantu siswa dalam belajar terutama saat proses pembelajaran berlangsung. Menurut Suranti et al. (2016) model pembelajaran yang digunakan guru diharapkan mampu mempermudah guru dalam menyampaikan materi sehingga peserta didik dapat menguasai konsep Fisika dengan baik.

Berdasarkan hasil observasi di SMKN 4 Mataram, ada beberapa permasalahan yang peneliti temukan yaitu, proses pembelajaran IPA Terapan yang berlangsung di kelas $\mathrm{X}$ bidang Pariwisata menggunakan pembelajaran konvensional dengan metode ceramah, Penggunaan metode ini menyebabkan guru sebagai satusatunya pusat perhatian di dalam pembelajaran, sedangkan siswa hanya menerima pengetahuan dari guru (teachercenter), sehingga membuat siswa cenderung pasif dan sangat tergantung pada materi yang disampaikan guru. Dalam proses pembelajaran, siswa menggunakan bahan ajar berupa buku siswa, dimana substansi dari buku siswa tersebut masih bersifat umum, artinya masih banyak konsep yang tidak sesuai dengan program keahlian siswa di bidang pariwisata. Sehingga dari permasalahan tersebut, membuat siswa sulit memahami materi Fisika yang sedang dipelajari sehingga mengakibatkan hasil belajar siswa rendah. Hal ini ditunjukkan dari hasil ulangan semester I siswa kelas X bidang Pariwisata SMKN 4 Mataram tahun pelajaran 2015/2016 yang masih tergolong rendah dan rata-rata masih di bawah Kriteria Ketuntasan Minimum (KKM) seperti yang terlihat pada tabel 1 .

Tabel 1. Nilai Rata-Rata Ulangan IPA Terapan Semester I Tahun Pelajaran 2015/2016

\begin{tabular}{clcccc}
\hline \multirow{2}{*}{ No } & Kelas & Jumlah siswa & Nilai Rata-rata & KKM & Keterangan \\
& & 38 & 60 & 67 & Tidak Tuntas \\
\hline 1 & X Tata Boga 1 & 35 & 49 & 67 & Tidak Tuntas \\
2 & X Tata Boga 2 & 36 & 57 & 67 & Tidak Tuntas \\
3 & X Tata Boga 3 & 50 & 48 & 67 & Tidak Tuntas \\
4 & X Usaha Perjalanan Wisata & 35 & 64 & 67 & Tidak Tuntas \\
5 & X Akomodasi Perhotelan 1 & 34 & 37 & 67 & Tidak Tuntas \\
6 & X Akomodasi Perhotelan 2 & 40 & 41 & 67 & Tidak Tuntas \\
7 & X Akomodasi Perhotelan 3 & 33 & 61 & 67 & Tidak Tuntas \\
8 & X Kecantikan 1 & 33 & & Tidak Tuntas \\
9 & X Kecantikan 2 & & & & \\
\hline
\end{tabular}

(Sumber: Arsip Nilai Guru Mata Pelajaran IPA, 2015)

Melihat hal-hal tersebut, maka guru dituntut untuk dapat memilih dan menerapkan model pembelajaran yang sesuai berdasarkan kondisi siswa dengan tujuan supaya siswa berperan aktif dalam pembelajaran, sehingga mata pelajaran IPA 
Terapan tidak terkesan sulit dan membosankan serta kegiatan belajar mengajar akan lebih bermakna. Selain itu, diperlukan penyusunan bahan ajar sederhana yang sesuai dengan lingkungan sekitar dan bidang keahlian siswa, sehingga siswa mudah memahami dan mengaplikasikan materi pelajaran. Jadi, dari permasalahan di atas peneliti tertarik untuk melakukan penelitian terhadap pengaruh model pembelajaran langsung (direct instruction) berbantuan bahan ajar berbasis kontekstual terhadap hasil belajar siswa. Model pembelajaran Direct Instruction dilakukan dengan membangkitkan akal dan kemampuan anak didik secara logis (Subarno, 2013). Sedangkan menurut Arends (2001) juga mengatakan hal yang sama yaitu $A$ teaching model that is aimed at helping student learn basic skills and knowledge that can be taught in a step bystep fashion. For our purposes here, the model is labeled the direct instruction model.

Model pengajaran langsung ini dirancang khusus untuk menunjang proses belajar siswa yang berkaitan dengan pengetahuan prosedural dan pengetahuan deklaratif yang terstruktur dengan baik, yang dapat diajarkan dengan pola kegiatan yang bertahap, selangkah demi selangkah

Pembelajaran di sekolah bukan hanya mengandalkan guru sebagai pusat dari seluruh kegiatan pembelajaran, melainkan juga sumber yang digunakan untuk membantu peserta didik di dalam pembelajaran. Salah satunya adalah bahan ajar. Selain digunakan untuk membantu guru memberikan pembelajaran di dalam kelas, bahan ajar juga dapat digunakan peserta didik untuk membantu mempelajari materi pelajaran. Bahan ajar adalah seperangkat materi yang disusun secara sistematis, baik tertulis maupun tidak tertulis, sehingga tercipta lingkungan atau suasana yang memungkinkan peserta didik untuk belajar (Ahmad, et al., 2011).

Pendekatan kontekstual adalah sebuah pendekatan dalam pembelajaran yang menekankan pada keterlibatan peserta didik secara utuh dalam mengkonstruksi materi yang dipelajari dan menghubungkannya dengan konsep kehidupan mereka Jadi bahan ajar berbasis kontekstual adalah bahan ajar yang komponen kegiatan belajarnya dikaitkan dengan objek-objek atau kejadian-kejadian aktual di dunia nyata yang akrab dengan kehidupan peserta didik.

Dapat disimpukan bahwa model pembelajaran direct instruction berbantuan bahan ajar berbasis kontekstual adalah suatu model pembelajaran langsung yang menggunakan media berupa bahan ajar yang disusun berbasis kontekstual yang membuat siswa bisa dengan mudah memahami materi secara bertahap yang tentunya dikaitkan dengan kehidupan nyata siswa. Adapun sintaks yang model pembelajaran direct instruction berbantuan bahan ajar berbasis kontekstual dapat dilihat pada tabel 2 berikut.

Tabel 2. Sintak Model Pembelajaran Direct Instruction berbantuan Bahan Ajar berbasis Kontekstual

\begin{tabular}{|c|c|c|}
\hline Kegiatan & Sintaks Pembelajaran & Kegiatan Guru \\
\hline Pendahuluan & $\begin{array}{l}\text { Fase } 1 \mathrm{DI} \text { (menyampaikan } \\
\text { tujuan pembelajaran dan } \\
\text { mempersiapkan siswa) }\end{array}$ & $\begin{array}{l}\text { - Menyiapkan siswa untuk berdoa dan belajar } \\
\text { - Guru meminta siswa untuk mempersipkan bahan ajar } \\
\text { - Guru menginformasikan tujuan pembelajaran yang akan } \\
\text { dicapai pada pertemuan tersebut }\end{array}$ \\
\hline
\end{tabular}

Fase 2 DI melibatkan siswa untuk melakukan demonstrasi 


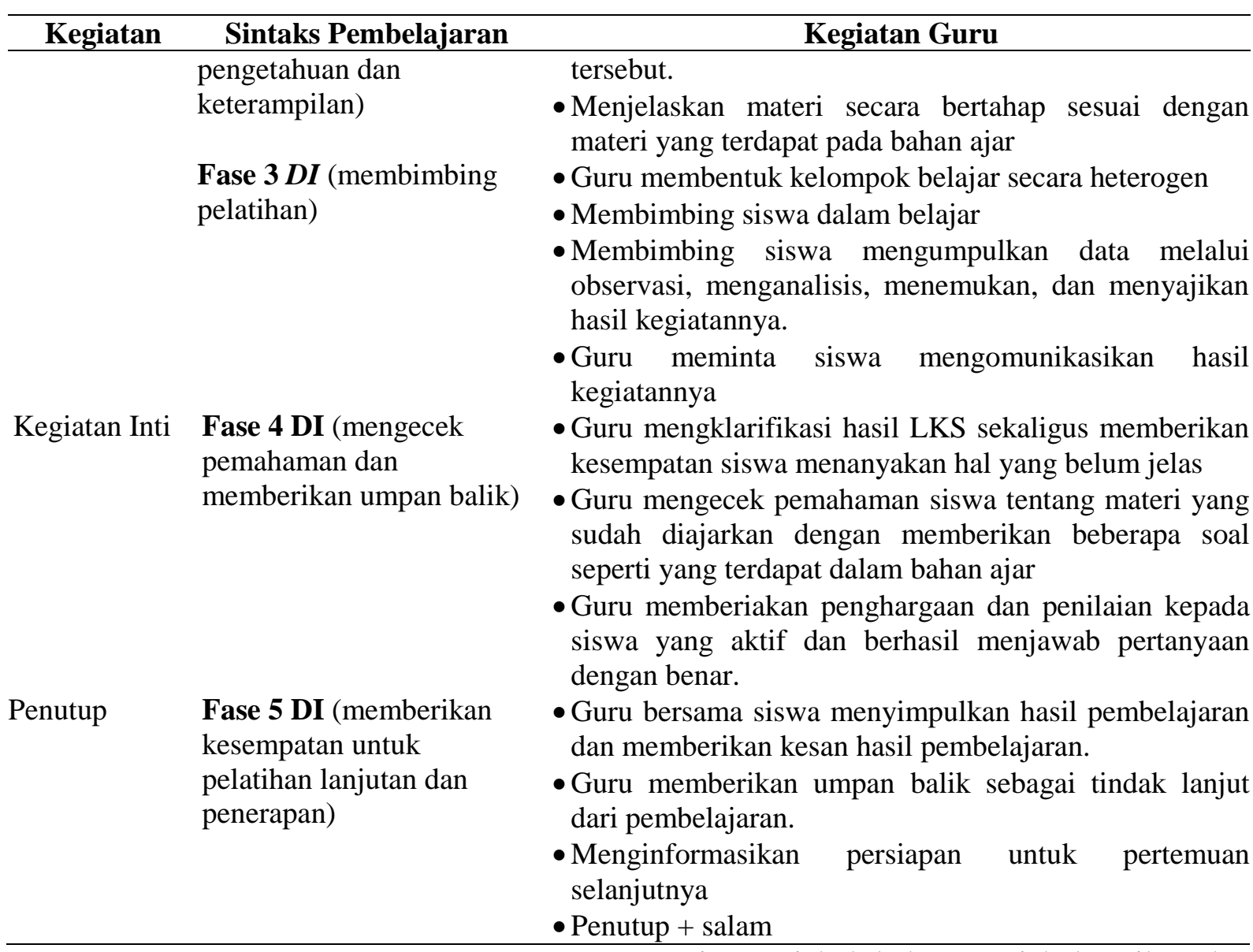

Keberhasilan dari keseluruhan langkah-langkah tersebut dapat diukur dengan hasil belajar siswa yang diuji dengan instrument berupa soal tes. Hasil belajar adalah perubahan kemampuan yang diperoleh setelah pelaksanaan kegiatan pembelajaran (Gunada, et al., 2015). Hasil belajar pada penelitian ini mengacu pada taksonomi Bloom, yakni pada ranah kognisi. Adapun ranah kognisi dalam taksonomi Bloom yaitu mengingat (C1), memahami (C2), mengaplikasikan (C3), menganalisis (C4), menyintesis (C5), dan mengevaluasi (C6).

\section{METODE PENELITIAN}

Jenis penelitian ini adalah penelitian eksperimen, yang merupakan metode penelitian yang mengungkap hubungan antara dua variabel atau lebih atau mencari pengaruh suatu variabel terhadap variabel lainnya. Pada penelitian ini ada tiga variabel yang menjadi fokus penelitian

yaitu variabel bebas, variabel terikat dan variabel kontrol. Variabel bebas adalah model pembelajaran, variabel terikat adalah hasil belajar IPA Terapan siswa pada materi Fisika, dan variabel kontrol adalah berupa kemampuan awal kelas eksperimen dan kelas kontrol dianggap sama, guru, materi, tujuan pembelajaran, instrumen yang digunakan, dan cara penilaian. Desain penelitian yang digunakan adalah posttestonly control group design, yaitu dalam penelitian ini hanya dilakukan posttest. Data awal yang digunakan untuk mengetahui homogenitas kemampuan awal siswa yaitu dengan menggunakan nilai semester I kelas X SMKN 4 Mataram. Desain penelitiannya dapat dilihat pada Tabel 3 berikut.

Tabel 3. Desain Penelitian

\begin{tabular}{lcc}
\hline Kelompok & Perlakuan & Posttest \\
\hline Eksperimen & $\mathrm{X}$ & $\mathrm{O}_{1}$ \\
Kontrol & - & $\mathrm{O}_{2}$ \\
\hline & \multicolumn{3}{c}{ (Setyosari, 2013) }
\end{tabular}


Keterangan:

$\mathrm{X}=$ Pembelajaran pada kelas eksperimen menggunakan model pembelajaran direct instruction berbantuan bahan ajar berbasis kontekstual pada kelas eksperimen.

- = Pembelajaran secara konvensional

$\mathrm{O}_{1}=$ Nilai tes akhir kelas eksperimen.

$\mathrm{O}_{2}=$ Nilai tes akhir kelas kontrol. Adapun Teknik pengambilan sampel dilakukan dengan teknik purposive sampling, yakni teknik pengambilan sampel di mana peneliti mempunyai pertimbangan-pertimbangan khusus berkenaan dengan sampel yang diambil. Sampel yang dipergunakan dalam penelitian ini yaitu siswa kelas $\mathrm{X}$ Tata Boga, yaitu X Tata Boga 2 yang berjumlah 35 siswa sebagai kelas eksperimen dan $X$ Tata Boga 3 yang berjumlah 36 siswa sebagai kelas kontrol. Pertimbangan peneliti mengambil sampel tersebut karena keterkaitan materi yang peneliti ambil dengan jurusan Tata Boga. Materi yang diambil yaitu tentang Suhu dan Kalor yang memiliki banyak keterkaitan dengan jurusan Tata Boga terutama dalam kegiatan memasak.

Tehnik pengumpulan data dilakukan dengan metode tes hasil belajar siswa yang dilakukan hanya sekali posttest saja menggunakan instrument soal yang sudah diujikan. Instrumen soal yang disiapkan dalam penelitian ini yaitu 40 butir soal yang terlebih dahulu duji validitas, reabilitas, taraf kesukaran dan daya beda soalnya di kelas yang lain yang sudah pernah mempelajari materi tersebut. Tempat pengujian instrmen dalam penelitian ini yaitu di kelas X Tata Boga 1. Hasil belajar tersebut dianalisis dengan uji validitas, realibilitas, tingkat kesukaran dan daya beda soal. Berdasarkan hasil uji coba 40 butir soal diperoleh 25 soal yng baik digunakan untuk posttest. Analisis validitas soal menggunakan rumus product moment dan untuk uji realibilitas soal mengunakan rumus Spearman-Borwn, indeks kesukaran soal untuk tingkat kesukaran soal dan indeks diskriminasi untuk daya beda soal. Analisis data menggunakan statistik parametrik t-test polled varians dengan kriteria uji dua pihak, yang sebelumnya telah diuji normalitas data menggunakan uji chi kuadrat dan homogenitas data menggunakan uji F. Data yang diuji statistiknya adalah data hasil posttest.

\section{HASIL DAN PEMBAHASAN}

Penelitian ini bertujuan untuk mengetahui pengaruh model pembelajaran direct instruction berbantuan bahan ajar berbasis kontekstual terhadap hasil belajar IPA Terapan pada materi Fisika siswa kelas $\mathrm{X}$ SMKN 4 Mataram tahun ajaran 2015/2016. Perlakuan yang diberikan berupa model pembelajaran direct instruction berbantuan bahan ajar berbasis kontekstual pada kelas eksperimen dan pembelajaran konvensional diterapkan pada kelas kontrol.

Hasil dari penelitian ini adalah deskripsi hasil belajar tes akhir (post test) difokuskan hanya pada ranah penilaian koognitif dengan menggunakan uji hipotesis. Dalam penentuan uji hipotesis yang digunakan data hasil post test diuji normalitas dan homogenitas datanya terlebih dahulu.

1. Deskripsi Data Hasil Penilitian

Data hasil belajar IPA Terapan pada materi fisika siswa diperoleh melalui post test yang diberikan pada kelas eksperimen dan kelas kontrol setelah diberi perlakuan yaitu model pembelajaran direct instruction berbantuan bahan ajar berbasis kontekstual. Hasilnya dapat dilihat pada table 4 berikut. 
Tabel 4 Data Hasil Post Test

\begin{tabular}{cccccccc}
\hline \multirow{2}{*}{ Kelas } & $\begin{array}{c}\text { Jumlah } \\
\text { Siswa }\end{array}$ & $\begin{array}{c}\text { Nilai } \\
\text { Terendah }\end{array}$ & $\begin{array}{c}\text { Nilai } \\
\text { Tertinggi }\end{array}$ & Rata-rata & Variansi & KKM & Keterangan \\
\hline Eksperimen & 29 & 16 & 88 & 61,38 & 263,17 & 57 & Tuntas \\
Kontrol & 30 & 16 & 76 & 49,07 & 238,27 & 57 & Tidak Tuntas \\
\hline
\end{tabular}

Dalam bentuk grafik dapat diperlihatkan seperti pada gambar 1 berikut.

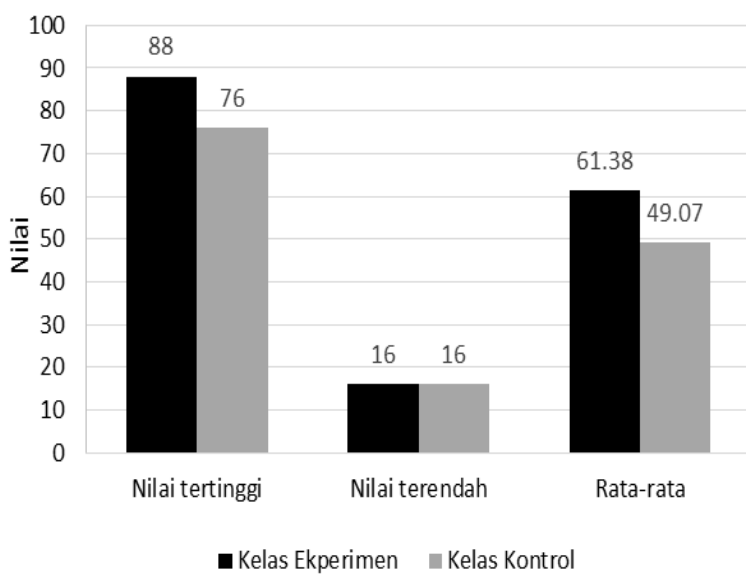

Gambar 1. Grafik Hasil Post Test

Berdasarkarn data pada tabel 4 di atas diperoleh nilai rata-rata untuk kelas eksperimen dan kelas kontrol masingmasing sebesar 61,38 dan 49,07. Terlihat bahwa kelas eksperimen nilai rata-rata hasil belajar di atas Kriteria Ketuntasan Minimal (KKM) yang ditetapkan 57 berdasarkan hasil analisis penentuan KKM. Sedangkan kelas control nilai rata-ratanyanya berada di bawah KKM. Dari gambar 1 meskipun terlihat bahwa nilai tertinggi yang dicapai siswa berada pad akelas eksperimen, tetap data harus dianlisis menggunakan uji hipotesis untuk menentukan pengaruh perlakuan yang diberikan terhadap hasil belajar.

Data hasil belajar ini yang akan diuji hipotesisnya. Artinya tidak membandingkan hasil belajar ini dengan nilai rata-rata seperti yang terliat pada table 1 di atas. Data hasil post test ini terlebih dahulu diuji normalitas dan homogenitas data untuk mengetahui uji hipotesis yang akan digunakan untuk analisi datanya.

Uji normalitas menggunakan rumus chi kuadrat pada taraf signifikan 5\% dengan $\mathrm{db}=\mathrm{k}-1$. Hasil perhitungan uji normalitas dapat dilihat pada tabel 5 berikut.

Tabel 5. Hasil Uji Normalitas

\begin{tabular}{ccccc}
\hline Kelas & Jumlah Siswa & $\chi^{2}$ hitung & $\chi^{2}$ tabel & Kriteria \\
\hline Eksperimen & 29 & 7,42 & 11,070 & Normal \\
Kontrol & 30 & 10,33 & 11,070 & Normal \\
\hline
\end{tabular}

Berdasarkan Tabel 5 di atas, terlihat bahwa nilai $\chi^{2}{ }_{\text {hitung }}<\chi^{2}$ tabel baik pada kelas eksperimen mapun kelas kontrol. Hal ini menunjukan bahwa data hasil belajar IPA Terapan siswa pada kedua kelas terdistribusi normal. Uji homogenitas bertujuan untuk mengetahui persamaan (ujit) yang akan digunakan dalam melakukan uji hipotesis.
Uji homogenitas menggunakan persamaan uji-F. Hasil perhitungan uji homogenitas dapat dilihat pada tabel 6 berikut. Berdasarkan tabel 6 tersebut terlihat bahwa hasil perhitungan didapatkan nilai $F_{\text {hitung }}$ sebesar 1,10 dan $F_{\text {tabel }}$ sebesar 1,88, sehingga dapat dilihat bahwa $F_{\text {hitung }}<$ $\mathrm{F}_{\text {tabel }}$ maka dapat dikatakan data hasil belajar fisika siswa tersebut homogen.

Tabel 6. Hasil Uji Homogenitas

\begin{tabular}{lccccc}
\hline \multicolumn{1}{c}{ Kelas } & Jumlah Siswa $(\mathrm{n})$ & Varians & $\mathrm{F}_{\text {hitung }}$ & $\mathrm{F}_{\text {tabel }}$ & Kriteria \\
\hline Eksperimen & 29 & 263,17 & \multirow{2}{*}{1,10} & \multirow{2}{*}{1,88} & \multirow{2}{*}{ Homogen } \\
Kontrol & 30 & 238,27 & & & \\
\hline
\end{tabular}


2. Uji Hipotesis

Dalam penelitian ini, uji hipotesis dilakukan untuk mengetahui pengaruh perlakuan yang diberikan terhadap hasil belajar hanya pada ranah koognitifnya saja. Setelah melakukan uji homogenitas dan uji normalitas sampel dari data hasil belajar post test, diperoleh bahwa siswa berasal dari populasi yang berdistribusi normal dan memiliki varians yang homogen sehingga uji hipotesis yang digunakan adalah uji statistik parametrik. Adapun uji statistik parametrik yang digunakan dalam penelitian ini adalah uji-t satu pihak dengan menggunakan rumus $t$-test polled varians.

Hasil analisis uji hipotesis data terhadap hasil belajar IPA Terapan siswa pada materi Fisika dapat dilihat pada tabel 7 berikut.

Tabel 7. Hasil Analisis Hipotesis Post Test

\begin{tabular}{ccccccc}
\hline Kelas & $\begin{array}{c}\text { Jumlah } \\
\text { Siswa }(\mathrm{n})\end{array}$ & $\begin{array}{c}\text { Rata-rata } \\
(\bar{X})\end{array}$ & $\begin{array}{c}\text { Standar } \\
\text { deviasi }(\mathrm{Sd})\end{array}$ & Varians & $t_{\text {hitung }}$ & $t_{\text {tabel }}$ \\
\hline Eksperimen & 29 & 61,45 & 16,47 & 271,26 & 2,89 & 2,00 \\
Kontrol & 30 & 49,23 & 16,00 & 256,00 & & \\
\hline
\end{tabular}

Berdasarkan hasil analisis data menggunakan data kelompok diperoleh nilai rata-rata hasil belajar untuk kelas eksperimen dan kelas kontrol masingmasing 61,38 dan 49,23. Dari kedua nilai tersebut terlihat bahwa nilai rata-rata kelas eksperimen lebih tinggi daripada nlai ratarata kelas kontrol. Hasil uji hipotesis menunjukkan bahwa $T_{\text {hitung }}>T_{\text {tabel }}$ itu artinya bahwa terdapat pengaruh pemberian berupa model pembelajaran direct instruction berbantuan bahan ajar berbasis kontekstual terhadap hasil belajar IPA Terapan siswa kelas X SMKN 4 Mataram tahun ajaran 2015/2016. Faktor pemberian perlakuan berupa pembelajaran direct instructuon berbantuan bahan ajar berbasis kontekstual menyebabkan hasil belajar post test pada kelas eksperimen lebih tinggi daripada hasil belajar post test pada kelas kontrol yang diberikan perlakuan berupa pembelajaran konvensional.

Model pembelajaran direct instruction ini merupakan bentuk dari pendekatan yang berorientasi kepada guru (teacher centered approach) Model pembelajaran langsung ini sangat ditentukan oleh pendidik, artinya pendidik berperan penting dalam proses pembelajaran. Dalam strategi pembelajaran ini peserta didik tidak dituntu untukmenemukan materi karena materi pelajaran sudah jadi. Pendidik secara langsung menyampaikan objek materi, sedangkan peserta didik hanya dating menerima materi secara langsung dari pendidik. Menurut Sofan et al., (2010) ada lima tahap yang harus diketahui guru dalam menggunakan direct instruction yaitu. 1) Guru memulai pembelajaran dengan menjelaskan tujuan pembelajaran khusus serta menginformasikan latar belakang dan pentingnya materi pembelajaran. 2) Guru menginformasikan pengetahuan secara bertahap atau mendemonstrasikan secara benar. 3) Guru membimbing pelatihan awal dengan cara meminta siswa melakukan kegiatan yang sama dengan kegiatan yang telah dilakukan guru dengan panduan LKS. 4) Guru mengamati kegiatan siswa untuk mengetahui kebenaran pekerjaan sambil memberi umpan balik. 5) Guru memberikan kegiatan pemantapan agar siswa berlatih sendiri menerapkannya dalam kehidupan sehari-hari, mislanya dalam bentuk tugas. Jadi pendidik harus benar benar menguasai materi pembelajaran dan kndisi kelas, serta terampil dalam komunikasi saat menyampaiakna materi.

Hasil peneiltan yang dilakukan oleh Nasution et al., (2013) tentang efektivitas 
model pembelajaran direct instruction terhadap hasil belajar. Hasil menunjukkan model pembelajaran direct instruction kurang efektif dalam dalam meningkatkan hasil belajar siswa. Dari hasil penelitian tersebut memungkinkan diakaibatkan oleh tidak adanyanya media bantu yang digunkan untuk mendukung model pembelajaran direct instruction tersebut sehingga guru kesulitan pada saat menyampaikan materi pembelajaran di kelas. Oleh karenanya dibutuhkan media atau alat bantu yang dapat digunkakan oleh guru saat mengajar menggunakan model pembelajaran direct instruction. Hasil Penelitian lain yang dilakukan oleh Tihuluw et al., (2014) efektivitas model pembelajaran direct instruction berbantuan media presentasi dalam meningkatkan hasil belajar fisika siswa hasilnya menunjukkan cukup efktif. Zaini et al., (2015) juga melakukan penelitian tentang pangaruh model pembelajaran direct instruction melalui pemodelan korektif terhadap hasil belajar siswa. Hasilnya menunjukkan terdapat pengaruh yang signifikan.

Adanya media pembelajaran berupa bahan ajar berbasis kontektual yang diterapakan pada model pembelajaran direct instruction diharapakan dapat meningkatkan hasil belajar siswa. Bahan ajar berbasis kontekstual adalah bahan ajar yang komponen kegiatan belajarnya dikaitkan dengan objek-objek atau kejadian-kejadian aktual di dunia nyata yang akrab dengan kehidupan peserta didik. Penerapan model seperti ini pada kelas eksperimen memiliki keunggulan dalam mempelajari bahan keterampilan dasar (pengetahuan procedural) dan memperoleh informasi (pengetahuan deklaratif) yang diajarkan selangkah demi selangkah. Artinya pengajaran yang dirancang sangat sistematis sehingga dapat mempermudah siswa dalam memahami materi secara bertahap. Selain itu, siswa juga terlibat aktif dan antusias dalam sistem pembelajaran, karena pada prinsip model pembelajaran direct instruction selalu melibatkan siswa dalam melakukan demonstrasi pengetahuan, kemudian siswa melakukan percobaanpercobaan untuk menemukan suatu konsep, kemudian terakhir siswa akan diberikan umpan balik untuk mengetes pemahaman siswa terhadap suatu materi yang sudah dipelajari.Selain itu, penggunaan model pembelajaran direct instruction tersebut, juga menggunakan media bantu yaitu berupa bahan ajar berbasis kontekstual. Bahan ajar ini disusun secara sistematis dan teratur serta substansi materinya dikaitkan dengan kehidupan sehari-hari yaitu tentang konsep suhu dan kalor di bidang tata boga. Sehingga dapat mempermudah siswa untuk memahami materi yang diajarkan.

Pembelajaran konvensional dengan metode ceramah yang diterapkan pada kelas kontrol adalah metode belajar yang cara penyajiannya dihadapkan hanya kepada suatu masalah yang bisa berupa pernyataan atau pertanyaan yang bersifat problematis untuk dibahas dan dipecahkan bersama satau secara kolektif. Proses pembelajaran didalamnya siswa hanya mendengar dan mencatat setiap informasi yang disampaikan oleh guru. Hal ini membuat siswa kurang berperan secara aktif dan antusias belajar siswa rendah, sehingga dapat mempengaruhi hasil belajar siswa menjadi rendah pula.

Data hasil posttest menunjukkan terdapat perbedaan rata-rata hasil belajar siswa kelas eksperimen dengan kelas kontrol. Terlihat hasil posttest kelas eksperimen berada di atas KKM, sedangkan hasil posttest kelas kontrol berada di bawah KKM. Namun dalam penelitian ini pencapaian hasil belajar di atas KKM bukanlah menjadi tolak ukur utamanya, yang menjadi tolak ukur utamanya yaitu data hasil belajar setelah diberikan perlakuan (posttest) pada kedua kelas. 
Apakah terdapat perbedaan hasil belajar pada kelas eksperimen dan kelas kontrol. Hasil uji hipotesis posttest menunjukkan bahwa $T_{\text {hitung }}=2,899$ dan $\mathrm{T}_{\text {tabel }}=2,00$, itu artinya $\mathrm{T}_{\text {hitung }}>\mathrm{T}_{\text {tabel. }}$. Maka berdasarkan kriteria pengujian hipotesis $\mathrm{H}_{\mathrm{o}}$ ditolak dan $\mathrm{H}_{\mathrm{a}}$ ditolak, artinya bahwa terdapat pengaruh pemberian model pembelajaran direct instruction berbantuan bahan ajar berbasis kontekstual terhadap hasil belajar IPA Terapan siswa kelas X SMKN 4 Mataram tahun ajaran 2015/2016.

Temuan dalam penelitian ini memperkuat beberapa penelitian sebelumnya diantaranya penelitian yang dilakukan Wahyudi, Astriani, dan Nurhayati, (2002) menyatakan bahwa hasil belajar siswa yang diberi pembelajaran dengan model direct instruction secara signifikan lebih tinggi daripada hasil belajar siswa yang diberi pembelajaran konvensional pada materi pengukuran. Hal ini diperkuat oleh hasil penelitian Peso, et al (2013) dan Fitrajaya (2010) yang menyatakan bahwa penggunaan pembelajaran direct instruction lebih efektif daripada metode konvensional dalam meningkatkan hasil belajar siswa.

\section{PENUTUP}

Berdasarkan hasil penelitian dan pembahasan yang telah dilaksanakan maka dapat ditarik kesimpulan bahwa terdapat pengaruh model pembelajaran direct instruction berbantuan bahan ajar berbasis kontekstual terhadap hasil belajar IPA Terapan siswa kelas SMKN 4 Mataram tahun ajara 2015/2016. Berdasarkan kesimpulan dapat diberikan saran yaitu diharapkan pada penelitian selanjutnya dapat mengukur hasil belajar pada ranah afektif dan psikomotorik.

\section{REFERENSI}

Ahmad, F. \& Radiyono, F. 2011. Pengembangan Bahan Ajar Fisika Dasar I Berbasis Spreadsheet dengan Pendekatan Analitik dan Numerik . Jurnal Materi dan Pembelajaran Fisika, 1(1), 15-17.

Arends, R.,I., Kilcher, A. 2001. Teaching for student learning. New York: Routledge.

Gunada, I., W., Sahidu, H., Sutrio. 2015. Pengembangan Perangkat Pembelajaran Fisika Berbasis Masalah untuk Meningkatkan Hasil Belajar dan Sikap Ilmiah Mahasiswa. Jurnal Pendidikan Fisika dan Teknologi, 1(1), 38-46.

Gunawan, Harjono, A., Sutrio. 2015. Multimedia Interaktif dalam Pembelajaran Konsep Listrik bagi Calon Guru. Jurnal Pendidikan Fisika dan Teknologi, 1(1), 9-14.

Mahedy, N., S. 2010. Implementasi Media Pembelajaran Berbasis Teknologi Informasi dan Komunikasi untuk Meningkatkan Minat dan Motivasi Belajar IPA Mahasiswa. Seminar International APTEKINDO, 335-344.

Murniati, N., A. N. \& Mustika, I. 2011. Upaya Meningkatkan Hasil Belajar IPA Fisika Melalui Pembelajaran Praktikum dengan Memanfaatkan Alat dan Bahan di Lingkungan Sekitar pada Siswa Kelas VII SMP Negeri 4 Kragan Rembang Tahun Ajaran 2008/2009. Jurnal Penelitian Pembelajaran Fisika, 2(1), 89-99.

Nasution, M.A., Silaban, R., \& Muchtar, Z. 2013. Penerapan Model Pembelajaran yang Mampu untuk Meningkatkan Hasil Belajar Kimia dan Karakter Komunikatif serta Percaya Diri. Jurnal Ilmu Pendidikan Indonesia, 1(3), 29-38.

Nisrina, N., Gunawan, G., \& Harjono, A. (2016). Pembelajaran Kooperatif dengan Media Virtual untuk Peningkatan Penguasaan Konsep Fluida Statis Siswa. Jurnal 
Pendidikan Fisika dan Teknologi, 2(2), 66-72.

Peso, M.K. \& Sugiyono. 2013. Penggunaan Model Pembelajaran Langsung Dengan Metode Demonstrasi Untuk Meningkatkan Hasil Belajar Siswa Pada Materi Energi Dalam IPA. Jurnal Pendidikan dan Pembelajaran UNTAN, 2(9), 1-10.

Setyosari, P. 2013. Metode Penelitian Pendidikan dan Pengembangan Edisi 3. Jakarta: Kencana Pramedia Group.

Sofan, A. \& Ahmadi, L.K. (2010). Proses Pembelajaran Kreatif dan Inofatif Dalam Kelas. Jakarta: Prestasi Pustaka Publisher.

Subarno. 2013. Penggunaan Direct Instruction Berbasis Lingkungan untuk Peningkatan Domain Afektif IPA Fisika Pada Siswa Kelas VII B SMP Negeri 26 Purworejo Tahun Pelajaran 2012/2013. Jurnal Pendidikan Fisika, 2(1), 24-26.

Suranti, N. M. Y., Gunawan, G., \& Sahidu, H. (2016). Pengaruh Model Project Based Learning Berbantuan Media Virtual Terhadap Penguasaan Konsep Peserta didik pada Materi Alat-alat Optik. Jurnal Pendidikan Fisika dan Teknologi, 2(2), 73-79.

Tihuluw, M., Y., Tulandi, D., Windia, I., W. 2014. Efektivitas Model Pembelajaran Langsung (Direct Instruction) Berbantuan Media Presentasi dalam Meningkatkan Hasil Belajar Fisika Siswa. JSME MIPA UNIMA. 2(8).

Wahyudi. A., \& Nurhayati. 2002. Pengaruh Model Pembelajaran Langsung (Direct Instruction) Terhadap Hasil Belajar Fisika Siswa. Jurnal Pendidikan Fisika, 2(1), 15-19.

Zaini, Sutrio, \& Gunawan. 2015. Pengaruh Pembelajaran Fisika Menggunakan Direct Instruction (DI) Melalui Pemodelan Korektif Terhadap Hasil Belajar Fisika Siswa Kelas VIII SMPN 2 Labuhan Haji Tahun Ajaran
2013-2014. Jurnal Pendidikan Fisika dan Teknologi, 1(2), 136-139. 